УДК 361.31

(C) 2017

\author{
Прасолов С. Я., кандидат технічних наук \\ Бєловол С. А., кандидат технічних наук \\ Мацаков А. В., магістрант \\ Полтавська державна аграрна академія
}

Бєловол Ю. Ю., аспірант

Український науково-дослідний інститут прогнозування та

випробування техніки і технологій для сільськогосподарського виробництва ім. Леоніда Погорілого

\title{
УДОСКОНАЛЕННЯ ВЕРТИКАЛЬНО-ФРЕЗЕРНОГО АДАПТЕРА ДЛЯ СМУГОВОГО ОБРОБІТКУ ГРУНТУ
}

\section{Рецензент - доктор сільськогосподарських наук, професор П. В. Писаренко}

\begin{abstract}
У статті наведено аналіз відомих технологій $i$ конструкиій машин та робочих органів для передпосівного обробітку грунту; обтрунтовано доцільність застосування технологій смугового обробітку трунту в лісостеповій зоні Украӥни; визначено перспективні напрями вдосконалення трунтообробних знарядь. Для запропонованого технічного рішення вдосконалення вертикально-фрезерного адаптера визначено оптимальні показники кінематичного режиму та кількості робочих елементів, чим гарантується якість проведення рівномірного смугового обробітку трунту. Впровадження вертикально-фрезерного адаптера запропонованої конструкиії з обтрунтованими параметрами забезпечить високу якість та рівномірність обробітку робочої зони, ефективне рихлення трунту, вирівняний профіль дна борозни та обробленої поверхні при раціональних показниках енергоємності та продуктивності технологічного процесу.
\end{abstract}

Ключові слова: смуговий обробіток трунту, вертикально-фрезерний адаптер, оптимізація параметрів.

Постановка проблеми. Досвід розвинутих країн світу вказує на те, що впровадження інноваційних технологій та покращання техніки в сільському господарстві $є$ запорукою високоефективного та прибуткового виробничого процесу.

Виробники сільськогосподарської продукції під час вибору технології обробітку грунту керуються економічною доцільністю та конкурентоспроможністю органічної продукції рослинництва.

Важливою рушійною силою в підвищенні ефективності землеробства $є$ удосконалення техніки обробітку грунту.

Різновидом мінімального обробітку грунту під час вирощування сільськогосподарських культур $\epsilon$ спосіб прямого посіву, за яким досягається зменшення енергозатрат під час підготовки грунту та посіву зернових культур, локальній підготовці грунту стрічково-смуговим способом на глибину посіву без обробітку міжряддя. Зни- ження собівартості продукції рослинництва можливе за відмови від використання застарілих енергоємних технологій та технічних засобів. Це зумовлює необхідність вдосконалення технічних засобів обробітку грунту.

Аналіз останніх досліджень і публікацій, у яких започатковано розв'язання проблеми. Результати досліджень процесу взаємодії робочих органів із грунтом поклав в основу землеробської механіки видатний вчений В. П. Горячкін [7]. У своїх працях вчений зазначає, що застосування ротаційних робочих органів для обробітку грунту $є$ перспективним. Методику проектування ротаційних робочих органів розробили, а з часом покращили Г. Н. Синєоков, Ф. М. Канарьов, Ю. І. Матяшин, І. М. Панов [19, $9,14,16]$. Теоретичні механіко-технологічні основи обробітку грунту створили А. С. Кушнарьов, В. І. Вєтохін [12, 4].

Нині використовуються ротаційні робочі органи на сучасних машинах, які виконують за один прохід декілька технологічних операцій і задовольняють агротехнічним вимогам енергоощадності, ефективності і якості технологічного процесу [3, 6, 10, 15, 18]. Вибір системи передпосівного обробітку грунту зробили, виходячи із результатів досліджень А. С. Кушнарьова, який оперує поняттями «обробка грунту», «оптимальна і рівноважна щільність», «урожай», «гумус», «орний горизонт» [13].

Інтегральним показником стану $є$ щільність грунту, а оперуючи поняттями «рівноважна щільність» $\mathrm{i}$ «оптимальна щільність» можна визначитись зі способом і глибиною обробітку грунту. Існує стійка закономірність між щільністю грунту і урожайністю сільськогосподарських культур. Збільшення оптимальної щільності $\left(1,1-1,25 \Gamma / \mathrm{cm}^{3}\right)$ грунту на $0,1-0,3 \Gamma / \mathrm{cm}^{3}$ призводить до зниження врожаю на 20-40 \% $[12,13]$. 


\section{ТЕХНІЧНІ НАУКИ}

Грунти України з розподілу рівноважної щільності в орному горизонті грунту по глибині шляхом експертної оцінки діляться на чотири типи: грунти I типу становлять - $19 \%$; грунти II типу $49,9 \%$; грунти III - 20,7 \%; грунти IV - 10,4\% [13].

Реальна економія палива може бути досягнута в разі освоєння нульового обробітку грунту (технологіï No-Till) на площах II типу розподілу щільності. Економія палива на таких грунтах становить 18-20 кг/га. Освоєння технології мінімальної (поверхневої) обробки грунту на площах III типу розподілу щільності дасть змогу зекономити паливо до 8-12 кг/га [2, 24].

Таким чином, спираючись на результати досліджень грунтів професора А. С. Кушнарьова та кліматичні умови лісостепової зони України, можна сказати, що розвиток та впровадження технологій нульової та мінімальної обробки грунту є перспективними для нашого регіону.

Одним 3 різновидів мінімальної обробки $\epsilon$ спосіб прямого посіву, що дає змогу досягти зниження енергозатрат під час підготовки грунту i посіву просапних культур, локальної підготовки грунту стрічково-смуговим способом на глибину посіву без обробітку міжряддя. Такий обробіток називається стрічково-смуговим (Strip-till), тобто виключається енерговитратна операція одно-, дворазової суцільної культивації. У випадку застосування відомої технології стрічково-смугового обробітку підготовка грунту проводиться на ширину 6-8 см, при цьому міжряддя не обробляється. Оброблена смуга засівається і прикочується профільними катками. Для зернових культур відомий стрічковий посів шириною 5-6 см. Якісна підготовка грунту і посів стрічково-смуговим способом забезпечують більш рівномірний розподіл насіння за глибиною i їх укриття дрібно-грудкуватим грунтом у порівнянні із прямим висівом за технологією No-till. Застосування такого способу посіву дає змогу в цілому значно скоротити агротехнічні терміни на обробку та посів $[2,17,24]$.

А. П. Спіріним [21] були наведені розрахункові формули для енергозберігаючих прийомів обробки грунту. Наприклад, для порівняльної оцінки різних прийомів обробки доцільно користуватися питомою енергоємністю, що розраховується за формулою:

$$
\mathrm{E}=104 \mathrm{kcp} \cdot \alpha \text {, }
$$

де $\mathrm{kcp}$ - середній питомий опір грунту на одиницю перетину оброблюваного шару; $\alpha-$ глибина оброблюваного шару.

Встановлено, що енерговитрати на обробку грунту стрічково-смуговим способом залежно від ширини міжряддя становлять приблизно 915 \% від суцільної обробки. Смуговий обробіток грунту набуває поширення, що зумовлено тим, що для більшості регіонів країни характерним $є$ гострий дефіцит вологи, а використання такого способу сівби є одним із ефективних заходів іi накопичення і заощадження [18].

Принципи створення комбінованих агрегатів для вирощування сільськогосподарських культур на базі пасивних робочих органів відомі по працях П. М. Бурченко, А. А. Вілде та інших [3, 6]. Нині існує база результатів теоретичних та експериментальних досліджень, яка дає змогу продовжити вдосконалення конструктивних та технологічних параметрів робочих органів для передпосівного обробітку грунту.

За результатами аналізу відомих знарядь для передпосівного обробітку грунту встановлено, що активні робочі органи з вертикальною віссю обертання забезпечують якісне фрезерування грунту, яке дає змогу йому довше зберігати оптимальну структуру. Водночас виконується подрібнення рослинних решток та їх рівномірне розміщення у кореневмісному шарі грунту, що позитивно впливає на режим живлення культурних рослин $[1,18]$.

Для забезпечення оптимальних умов розвитку просапних культур, необхідно розробити технічні засоби, які б поєднували переваги енергозберігаючих технологій. Перспективною розробкою $\epsilon$ дослідження по вдосконаленню конструкції універсального фрезерного робочого органу 3 вертикальною віссю обертання, що проводились в ННЦ «ІМЕСГ» А. Л. Кириченко, під керівництвом М. П. Білоткача [11].

Таким чином, перспективним є дослідження роботи та вдосконалення конструкції вертикально-фрезерного адаптера для передпосівного обробітку грунту за ресурсозберігаючою технологією.

Виконані дослідження ставили за мету:

- провести аналіз науково-технічної інформації відомих технологій і конструкцій машин для передпосівного обробітку грунту;

- розробити конструкторську документацію та виготовити дослідний зразок вертикальнофрезерного адаптера;

- виконати вибір, обгрунтування та повірку вимірювальних приладів для проведення досліджень;

- розробити методику визначення показників впливових факторів та оптимальних значень якості роботи вертикально-фрезерного адаптера.

Завдання статmі - проведення досліджень процесу передпосівного обробітку грунту вертикально-фрезерним адаптером розробленої конс- 


\section{ТЕХНІЧНІ НАУКИ}

трукції, визначення залежності якості обробітку грунту від конструктивно-технологічних параметрів робочого органу.

Розробка конструкиії вертикально-фрезерного адаптера для смугового обробітку грунту. В основу теоретичних досліджень покладено кінематичний аналіз роботи запропонованого за технічним рішенням вертикально-фрезерного адаптера, побудову графоаналітичних залежностей для визначення роботоздатності конструкції та оптимізації ऑii конструктивно-технологічних параметрів.

Вертикально-фрезерний адаптер призначений для використання у ресурсозберігаючій технології - стрічково-смуговій обробці грунту (Striptill), яка включає комплекс операцій по обробці смуги поля (в основному стерньові фони), в які проводиться висів насіння сільськогосподарських культур з одночасним внесенням добрив та хімікатів. Перевагами технології $\epsilon$ економічна доцільність за рахунок зменшення енергоємності та паливних витрат; зниження ерозійних явищ та збереження родючості грунтів у порівнянні із традиційним обробітком; покращання умов розвитку культурних рослин у порівнянні 3 нульовим обробітком грунту. Із врахуванням грунтово-кліматичних умов регіонів розповсюдження стрічкової технології в Україні є перспективним. Проте стримується відсутністю комплексів машин, які б в достатній мірі задовольняли агротехнічним та енергетичним вимогам. Для зменшення паливних витрат та зниження негативного ущільнюючого впливу ходових систем енергетичних засобів на родючість грунтів доцільно проводити смуговий обробіток грунту одночасно i3 сівбою сільськогосподарських культур, що підвищує вимоги до якості обробітку. На задоволення вказаних потреб i спрямовані дослідження.

Вертикально-фрезерний робочий орган для смугового обробітку грунту містить приводні вали із вертикальною або крутонахиленою віссю обертання, де змонтовано зовнішній та внутрішній диски, яким через редуктор гідромотора або валу відбору потужності надається примусовий обертальний рух у зустрічних напрямках. На зовнішньому диску встановлені ріжучі елементи 3 активним кутом атаки в межах $\alpha_{1}=1-35^{\circ}$ та зовнішньою заточкою ріжучої кромки, а на внутрішньому диску встановлені ріжучі елементи із пасивним кутом атаки в межах $\alpha_{2}=1-35^{\circ}$ та внутрішньою заточкою ріжучої кромки [21].

Довжина ріжучих елементів підібрана 3 можливістю виконувати обробіток грунту на однакову глибину, яка визначається з біологічних особ- ливостей розвитку кореневої системи культурних рослин. На зовнішньому диску встановлюються від двох до восьми ріжучих елементів, а на внутрішньому - від двох до п'яти. Використовуються ріжучі елементи змінного, постійного перерізу по довжині та 3 кутом скручування $\beta=3-15^{\circ}$. Кут нахилу вісі вертикальнофрезерного робочого органу може змінюватись у вертикально-повздовжній площині в межах 1$20^{\circ}[1,5]$.

Матеріали і методи досліджень. Процес обробки грунту вертикально-фрезерним адаптером згідно 3 технічним рішенням характеризується складним рухом робочих елементів. Кожен робочий елемент у випадку взаємодії 3 грунтом створює зону рихлення. За недостатньої кількості робочих елементів виникають необроблені ділянки, а в разі збільшення їх кількості підвищуються енерговитрати на обробку. У зв’язку 3 цим правильний вибір і обгрунтування раціональної кількості робочих елементів $є$ необхідною умовою його роботи [5].

Експериментальні дослідження проводились згідно 3 методикою розробленою на основі нормативних документів та рекомендацій щодо випробувань ротаційних грунтообробних знарядь, відомих 3 науково-технічних джерел. Тривалість та строки проведення досліджень визначались КНД 46.16.02.16 «Техніка сільськогосподарська. Тривалість та агростроки проведення випробувань».

Лабораторно-польові дослідження проводились на основі СОУ 74.3-37-155:2004. «Випробування сільськогосподарської техніки. Машини i знаряддя для обробітку грунту». Перед початком досліджень визначались умови випробувань згідно $з$ ГОСТ 20915 «Сільськогосподарська техніка. Методи визначення умов випробування». Тип грунту і його назва за агрегатним складом визначались із грунтової карти господарства [20].

Вологість та щільність грунту визначались до початку досліджень за стандартною методикою та 3 використанням технічних рішень приладу та способу відбору проб грунту [8, 22]. Зразки зважувались на вагах лабораторних ВЛТК-500 3 точністю 0,01 г (ГОСТ 24104 «Ваги лабораторні. Загальні технічні вимоги»).

Твердість грунту визначалась на облікових ділянках у місцях визначення вологості грунтовим твердоміром Ревякіна, згідно 3 ДСТУ 5092:2008 «Якість грунту. Визначення твердості грунту твердоміром Ревякіна».

Для проведення експериментальних досліджень ефективності роботи вертикально-фрезерного адаптера в польових умовах була розроблена дослідна 


\section{TЕХНІЧНІ НАУКИ}

установка. Установка включала два адаптера, що дає можливість об'єктивно оцінити якість роботи вертикально-фрезерного адаптера.

Дослідна установка включає несучу раму, на якій змонтовано гідромотор. На опорах кріплення встановлені вертикально-фрезерні адаптери. Крутний момент на адаптери передається від гідромотора через пасову передачу, яка включає ведений і ведучий шківи, натяжний ролик і зубчатий пас.

На раму встановлено гряділь, на який встановлювалась дослідна установка. Від гідросистеми 3 номінальним тиском 16 МПа трактора через патрубки на гідромотор подавалась робоча рідина, чим адаптери приводились в обертовий рух. Глибина ходу адаптерів регулювалась опорним колесом.

Згідно із програмою експериментальних досліджень було передбачено контроль наступних показників роботи установки: кутової швидкості обертання дисків адаптера, поступальної швидкості агрегату дослідної установки встановленої на гряділь. Для цього було обрано та встановлено відповідне обладнання.

Дослідна установка виконана із можливістю регулювання значень кутової швидкості обертання дисків адаптера, згідно із умовами досліджень, на гідромотор встановлено регулювальний кран, що змінює тиск робочої рідини. Крім того, для визначення оптимальних параметрів кута атаки внутрішніх та зовнішніх ріжучих елементів, змінювалось його значення.

Проведення досліджень в польових умовах передбачало монтаж та агрегатування дослідної установки 3 енергетичним засобом та встановлення відповідних приладів для контролю показників їі роботи.

Контроль поступальної швидкості агрегату здійснювався за допомогою шляховимірного колеса зі встановленим на ньому індуктивним частотовимірювальним датчиком Д4В-1, що кріпилося до підніжки трактора. Тарувальний коефіцієнт - 9, за кількістю спиць шляховимірного колеса. Датчики пройшли тарування. Приймання та запис сигналу виконувався інформаційновимірювальною системою на базі тензопідсилювача «Spider-8» із програмним забезпеченням CatManExpress 4.5 для персонального комп'ютера, а дані зберігалися у форматі «*.xls» та визначались контрольні показники одночасно.

Для визначення взаємозв'язку регульованих параметрів вертикально-фрезерного адаптера iз показниками якості обробки грунту було складено центральний композиційний план третього порядку.
Використання системи «Spider-8» і оптимального плану експерименту дали змогу виконати експериментальні дослідження за один день, 3 мінімальними затратами праці та часу на налаштування досліджуваних параметрів дослідної установки, 3 виключенням впливу зміни умов випробувань на результати досліджень.

Налаштування дослідної установки проводились у попередньо-обгрунтованих межах, а саме: кут атаки ріжучих елементів $\alpha=0-30^{\circ}$; кутова швидкість обертання дисків ротаційних органів - $\omega=50-150$ хв-1; поступальна швидкість агрегату $-V=1,7-2,8 \mathrm{~m} / \mathrm{c}$.

Перед кожним заїздом адаптерам надавався обертовий рух до виходу на задані планом експерименту значення кутової швидкості, що контролювались за допомогою частотовимірювального датчика Д4В-1. Результати пошукових досліджень встановили, що суттєві зміни в показниках якості обробки в разі варіювання даного показника в заданих межах відмічались на трьох рівнях значимості, тому контрольними точками кутової швидкості визначені наступні значення: 50 хв-1, 100 хв-1, 150 хв-1.

Згідно $з$ теоретичними обгрунтуваннями щодо оптимального кінематичного режиму ротаційних органів, змінювалась поступальна швидкість агрегату на рівнях: $1,7 \mathrm{~m} / \mathrm{c}, 2,22 \mathrm{~m} / \mathrm{c}, 2,8 \mathrm{~m} / \mathrm{c}$.

Контролювалась поступальна швидкість за допомогою шляховимірного колеса згідно $з$ методикою описаною в РД 10.4.1. «Випробування сільськогосподарської техніки. Машини і знаряддя для глибокого обробітку грунту. Програма $\mathrm{i}$ методи випробувань».

Послідовність досліду. Після встановлення значень регульованих параметрів згідно з планом експерименту, адаптери опускались і занурювались у грунт на робочу глибину (8-12 см). Далі агрегат із заглибленими ротаційними органами проходив шлях близько 7-10 м до початку обробки залікових ділянок. Це було необхідно для виходу двигуна і дослідної установки на сталий режим роботи. Цей період відповідав значенням найменшої кореляції значень сигналів записаних інформаційно-вимірювальною системою «Spider-8».

Гребнистість дна борозни після обробки визначалась по висоті гребенів між двома сусідніми слідами робочих органів. Виміри проводились у 5 точках уздовж ряду 3 інтервалом 0,5 м на всю ширину захвату установки в триразовій повторності (два по ходу агрегату, два - в зворотньому напрямку). Для цього знімався розпушений шар грунту, по ширині ряду і на поверхню накладалась рейка і лінійкою вимірювалась від- 


\section{TEХНІЧНІ НАУКИ}

стань від дна борозни до нижньої сторони рейки.

Визначення кришення грунту. Відбирались через 1,5 години проби грунту на глибині обробки 3 облікової ділянки площею $0,25 \mathrm{~m}^{2}$ у чотириразовій повторності. Відібрані проби просівались через набір решіт, які розташовують у порядку зменшення діаметру отворів. Потім обережними коливальними рухами просіювався грунт через решета на відповідні фракції. Вміст кожного решета зважувався, 3 похибкою \pm 20 г.

Вміст ерозійно-небезпечних часток у шарі 0-5 см визначався шляхом - виміру на трьох облікових ділянках до та після проходу установки. Водночас совком відбиралась проба масою 2,53,0 кг. Проби доводились до повітряносухого стану, просівались через решето 3 діаметром отворів 1 мм та зважувались. Результати вимірів та обчислень масової частки ерозійнонебезпечної фракції грунту заносились у відомість. Щільність грунту після обробки визначалась за стандартною методикою.

Результати досліджень. Для встановлення

$$
\begin{aligned}
& Y_{1}=4,18+1,81 \cdot x 1+0,42 \cdot x 1^{2}-0,021 \cdot x 2+0,0001 \cdot x 2^{2}-0,0174 \cdot x 3+0,002 \cdot x 1 \cdot x 2+0,005 \cdot x 1 \cdot x 3 \\
& Y_{2}=-21,61+76,11 \cdot x 1-17,39 \cdot x 1^{2}+0,04 \cdot x 2+1,01 \cdot x 3-0,033 \cdot x 3^{2} \\
& Y_{3}=-10,78+4 \cdot x 1+0,29 \cdot x 2-0,001 \cdot x 2^{2}+0,044 \cdot x 3-0,075 \cdot x 1 \cdot x 2-0,001 \cdot x 2 \cdot x 3 .
\end{aligned}
$$

По результатам досліджень були складені рівняння регресії, за якими можна визначити оптимальні параметри обробки грунту адаптером. У рівняннях значимість коефіцієнтів визначалась за критерієм Стьюдента, а адекватність рівняння перевірялась за критерієм Фішера. 3 рівняння регресії виключаємо не значимі фактори і за уточненою математичною моделлю будуємо поверхні відгуку.

Залежність щільності грунту від кутової та поступальної швидкостей наведена на рисунку 1.

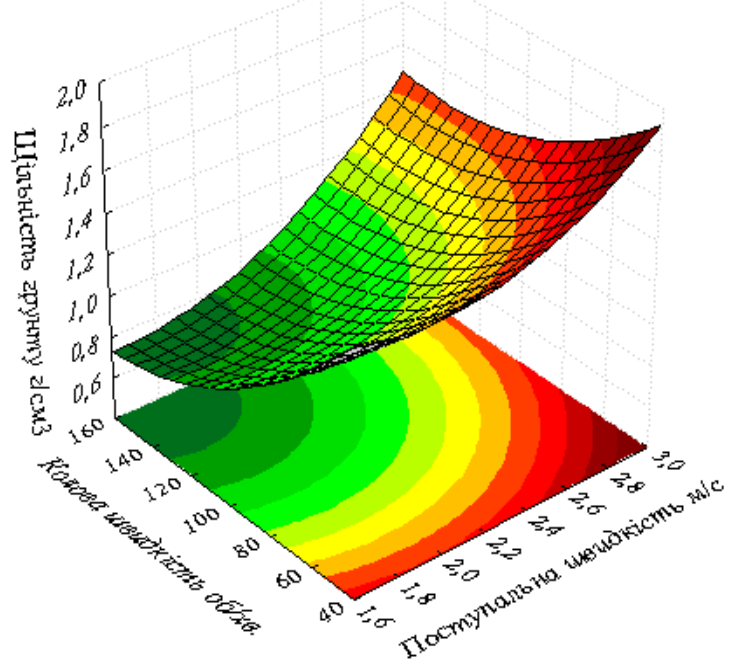

Рис. 1. Залежсність щиільності грунту від кутової та поступальноӥ швидкостей

3 рисунку 2 бачимо, що оптимальна щільність грунту досягається за високих значень кутової швидкості та середніх значень поступальної швидкості. 


\section{TEХНIЧНI НАУКИ}

Найбільше на фракційний склад впливають кут установки робочих елементів і поступальна швидкість. Для оцінки впливу взаємодії кутової та поступальної швидкості на фракційний склад будуємо поверхню відгуку (рис. 2).

3 рисунку 2 бачимо, що найбільший вміст фракцій оптимального (1-10 мм) діаметру спостерігається за високого рівня кутової - 100-120 хв-1. та середнього значення поступальної швидкості - 2,0$2,2 \mathrm{M} / \mathrm{c}$.

Проводимо аналогічний аналіз для рівняння регресії по визначенню профілю дна борозни (У3).

Для оцінки впливу взаємодії кута установки робочих елементів та кутової швидкості на профіль дна борозни будуємо поверхню відгуку (рис. 3).

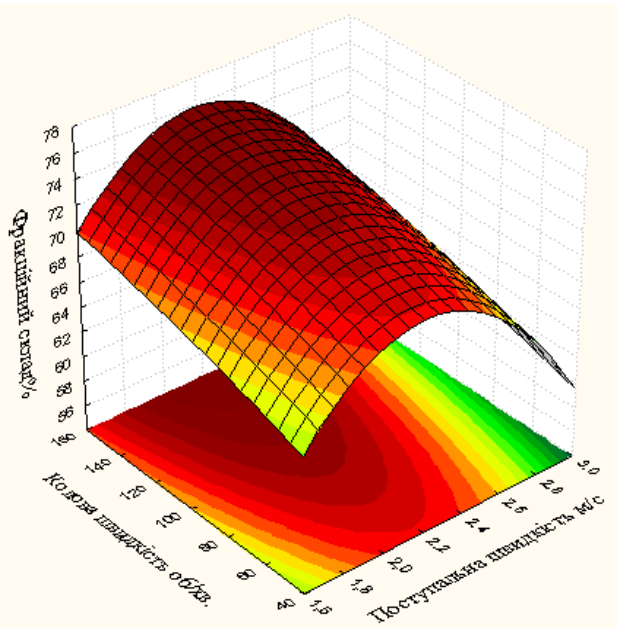

Рис. 2. Залежність фракційного складу трунту від кутової та поступальної швидкостей

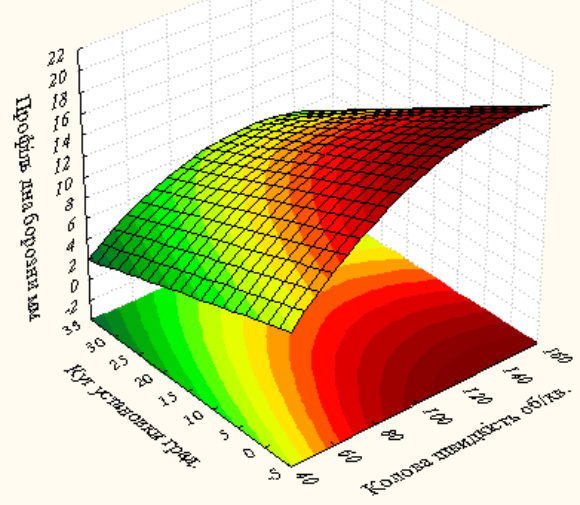

Рис. 3. Залежність профілю дна борозни від кута установки робочих елементів та колової швидкості

3 рисунку 3 бачимо, що відхилення від рівного профілю дна борозни спостерігається у випадку зростання кутової швидкості.

За результатами аналізу значимості впливових факторів визначаємо остаточний вигляд рівнянь регресії для досліджуваних показників якості. Для оптимізації конструктивно-технологічних параметрів адаптера задаємося умовами для знаходження оптимального режиму роботи і складаємо систему:

$$
\left\{\begin{array}{l}
4,18+1,81 \cdot x_{1}+0,42 \cdot x_{1}^{2}-0,021 \cdot x_{2}+0,0001 \cdot x_{2}^{2}-0,0174 \cdot x_{3}+0,002 \cdot x_{1} \cdot x_{2}+0,005 \cdot x_{1} \cdot x_{3}=1,1 \ldots 1,5 \\
-21,61+76,11 \cdot x_{1}-17,39 \cdot x_{1}^{2}+0,04 \cdot x_{2}+1,01 \cdot x_{3}-0,033 \cdot x_{3}^{2}=50 \ldots 80 \\
-10,78+4 \cdot x_{1}+0,29 \cdot x_{2}-0,001 \cdot x_{2}{ }^{2}+0,044 \cdot x_{3}-0,075 \cdot x_{1} \cdot x_{2}-0,001 \cdot x_{2} \cdot x_{3}=0 \ldots 10
\end{array}\right.
$$




\section{TЕХНІЧНІ НАУКИ}

Розв'язавши систему рівнянь (8), знаходимо оптимальні значення факторів: поступальна швидкість $-\mathrm{V}=\mathrm{X} 1=2,1-2,3$ м/с; кутова швидкість $-\omega=X 2=65-120$ хв-1.; кут нахилу $-\beta=X 3=10$ $14^{\circ}$, за яких передпосівний обробіток грунту вертикально-фрезерним адаптером буде виконаний відповідно до агротехнічних вимог.

Висновок. Згідно $з$ поставленою метою:

1. Виконано аналіз відомих технологій і конструкцій машин та робочих органів для передпосівного обробітку грунту та обрано напрям досліджень.

2. Підтверджена потреба вдосконалення конструкції та покращання параметрів вертикально-фрезерних робочих органів для смугового передпосівного обробітку грунту.

3. Визначено згідно з розробленим технічним рішенням кінематичний показник роботи вертикально-фрезерного адаптера, що гарантує доцільність проводити рівномірний передпосівний смуговий обробіток грунту. Встановлено, що під час використання кінематичного показника роботи $\lambda=1,1-2$, оптимальна кількість робочих елементів на зовнішньому диску становить 2-8 шт., а на внутрішньому 2-5 штук.

4. Обгрунтовані впливові фактори на роботу

\section{БІБЛІОГРАФІЯ}

1. Бєловол Ю. Ю. Обгрунтування параметрів вертикально-фрезерного адаптера для смугового обробітку грунту [текст] / Ю. Ю. Бєловол // Scientific Journal «ScienceRise». - №2 (2). - 2014. - C. 98-104.

2. Буга В. Г. Ленточно-бороздковый посев сои [текст] / В. Г. Буга // Механизация и электрификация социалистического сельского хозяйства. 1990. - №4. - С. 19-20.

3. Бурченко П. Н. Принципы создания комбинированных агрегатов для возделывания с.- . культур на базе пассивных рабочих органов [текст] / П. Н. Бурченко // Труды ВИМ. - Т. 63. М. : ВИМ, 1973. - $151 \mathrm{c.}$

4. Ветохин В. И. Тягово-приводные комбинированные почвообрабатывающие машины: Теория, расчет, результаты испытаний : монографія [текст] / [Ветохин В. И., Панов И. М., Шмонин В. А., Юзбашев В. А.]. - К. : Феникс, 2009. - 264 с.

5. Вертикально-фрезерний робочий орган для смугового обробітку грунту [текст] : пат. 107751 Україна, МПК6 А 01 В 33/06 / Бєловол Ю. Ю., Браженко С. А. ; заявник і патентовласник Бєловол Ю. Ю., Браженко С. А. - № а201310823 ; заявл. 09.09.2013 ; опубл. 10.02.2015, бюл. №3.

6. Вильде A. A. Комбинированные почвообрабатывающие машины [текст] / [Вильде А. А., вертикально-фрезерного адаптера: поступальна i кутова швидкість, кут встановлення робочих органів та оптимальні показники якості технологічного процесу: щільність грунту в оброблюваному шарі, фракційний склад грунту та профіль отриманої поверхні поля.

5. Визначені показники впливових факторів, отриманих за розробленою методикою відповідно до нормативних документів та матричного планування експериментів.

6. Проведена оптимізація конструктивнотехнологічних параметрів вертикальнофрезерного адаптера, які відповідно мають значення меж: поступальна швидкість - 2,1-2,3 м/с, кутова швидкість - 65-120 хв-1, кут встановлення робочих елементів $-10^{\circ}-14^{\circ}$.

Запропонований вертикально-фрезерний адаптер призначений для смугового обробітку грунту за ресурсозберігаючою технологією забезпечить рівномірність обробітку робочої зони; ефективне рихлення грунту, мульчування рослинних решток та їх взаємне перемішування; вирівняний профіль дна борозни та обробленої поверхні; стійкість руху машинно-тракторного агрегату та зниження енерговитрат технологічного процесу обробки грунту.

Цесниекс Ф. Х., Моритис Ю. П. и др.]. - Л. : Агропромиздат. Ленингр. Отд-ние, 1986. - 128 с.

7. Горячкин В. П. Собрание сочинений. Том первый [текст] / В. П. Горячкин. - М. : Колос, 1965. $-714 \mathrm{c}$.

8. ГОСТ Р 8.563-96. Методики выполнения измерений [текст]. - [Действ. от 1996-05-23]. М. : Госстандарт России, 1996. - 20 с.

9. Канарёв Ф. М. Ротационные почвообрабатывающие машины и орудия [текст] / Канарёв Ф. М. - М. : Машиностроение, 1983. - 142 с.

10.Киселёв C. Н. Ротационные машины в экологическом земледелии [текст] / С. Н. Киселёв, Н. В. Перевозчикова // Вестник МГАУ. Серия: «Техника и технологии агропромышленного комплекса». - 2008. - №2. - С. 67-69.

11. Кириченко A. Л. Аналіз енергетичних показників універсального фрезерного робочого органу $з$ вертикальною віссю обертання за даними експериментальних досліджень [текст] / А. Л. Кириченко // Механізація та електрифікація сільського господарства. - Глеваха. - 2011. - Вип. 95. - С. 91-100.

12. Кушнарьов A. C. Механико-технологические основы обработки почвы [текст] / А. С. Кушнарьов, В. И. Кочев. - К. : Урожай, 1989. -138 c. 


\section{TEХНІЧНІ НАУКИ}

13. Кушнарёв A. C. Новый взгляд на обработку почвы [текст] /А. С. Кушнарёв // Збірник наукових праць. - Дослідницьке : УкрНДІПВТ ім. Л. Погорілого, 2009. - Вип. 13 (27), кн.2. - С. $15-28$.

14. Матяшин Ю. И. Силовой анализ работы ротационных почвообрабатывающих машин [текст] / И. Ю. Матяшин, Н. Ю. Матяшин, А. Н. Матяшина // Вестник МГАУ. - 2008. - №3. - С. $46-51$.

15. Науково-технічна експертиза технікотехнологічних рішень систем обробітку грунту [текст] / [В. І. Кравчук, В. В. Погорілий, Л. П. Шустік та ін.]. - К. : Фенікс, 2008. - 50 с.

16. Панов И. М. Перспективы развития конструкций почвообрабатывающих машин и орудий [текст] / И. М. Панов. - Механизация и электрификация сельского хозяйства. - 1987. - №3. C. $13-16$.

17. Пастухов B. I. Якість механізованих технологічних операцій і біопотенціал польових культур : Наукові рекомендації для працівників механізованого рослинництва [текст] / В. І. Пастухов. - Х. : Ранок, 2002. - $124 \mathrm{c}$.

18. Прасолов С. Я. Аналіз знарядь для виконання передпосівної обробки [текст] / С. Я. Прасолов, Ю. Ю Бєловол // Збірник наукових праць Вінницького національного аграрного університету. - Серія: «Технічні науки». -
Вінниця, 2012. - Випуск 11. - Т. 2 (33). - С. 245250.

19. Синеоков Г. Н. Теория и расчет почвообрабатывающих машин [текст] / Г. Н. Синеоков, И. М. Панов. - М. : Машиностроение, 1977. $312 \mathrm{c}$.

20. СОУ 74.3-37-127:2004. Випробування сільськогосподарської техніки. Машини і знаряддя для обробітку просапних культур [текст]. Офіц. вид. - К. : Міністерство аграрної політики України, 2006. - 54 с.

21. Спирин А. П. Энергосберегающие приемы безотвальной обработки почвы [текст] / А. П. Спирин // Техника в сельском хозяйстве. №4. -1998 . - C. 20-23.

22. Спосіб відбору проб [текст] : пат. 55045 Україна, МПК6 А 01 C1/00 / Чекрізов І. А., Удовиченко Г. А., Кішек М. Г., Бовсуновський В. М., Прасолов С. Я. ; заявник і патентовласник Чекрізов I. А., Удовиченко Г. А. - № u201002731 ; заявл. 11.03.2010; опубл. 10.12.2010, бюл. №23.

23. Тарасенко Б. И. Плотность сложения пахотного слоя и урожайность с.-х. культур на черноземе Кубани [текст] / Б. И. Тарасенко // Почвоведение. - 1979. - №8. - С. 54-60.

24. Altikat $S$. Effects of strip width and tractor forward speed on sowing uniformity of maize and sunflower. Bulg. J. Agric. Sci., 19. - 2013. - 375382. 